\title{
Phenotypic Definition of the Progenitor Cells with Erythroid Differentiation Potential Present in Human Adult Blood
}

\author{
Valentina Tirelli, ${ }^{1}$ Barbara Ghinassi, ${ }^{2}$ Anna Rita Migliaccio, ${ }^{2}$ Carolyn Whitsett, ${ }^{2}$ \\ Francesca Masiello, ${ }^{1}$ Massimo Sanchez, ${ }^{1}$ and Giovanni Migliaccio ${ }^{1}$ \\ ${ }^{1}$ Cell Biology and Neuroscience, Superior Health Institute, 00161 Rome, Italy \\ ${ }^{2}$ Tisch Cancer Institute, Mount Sinai School of Medicine, New York, NY 10029, USA \\ Correspondence should be addressed to Anna Rita Migliaccio, annarita.migliaccio@mssm.edu
}

Received 23 May 2011; Accepted 22 June 2011

Academic Editor: Michel Sadelain

Copyright ( $) 2011$ Valentina Tirelli et al. This is an open access article distributed under the Creative Commons Attribution License, which permits unrestricted use, distribution, and reproduction in any medium, provided the original work is properly cited.

\begin{abstract}
In Human Erythroid Massive Amplification (HEMA) cultures, AB mononuclear cells (MNC) generate 1-log more erythroid cells (EBs) than the corresponding CD34 $4^{\text {pos }}$ cells, suggesting that MNC may also contain CD34 ${ }^{\text {neg }}$ HPC. To clarify the phenotype of $\mathrm{AB}$ HPC which generate EBs in these cultures, flow cytometric profiling for CD34/CD36 expression, followed by isolation and functional characterization (colony-forming-ability in semisolid-media and fold-increase in HEMA) were performed. Four populations with erythroid differentiation potential were identified: $\mathrm{CD} 34^{\text {pos }} \mathrm{CD} 36^{\text {neg }}(0.1 \%)$; $\mathrm{CD} 34^{\text {pos }} \mathrm{CD} 36^{\text {pos }}$ (barely detectable- $0.1 \%)$; $\mathrm{CD} 34^{\text {neg }} \mathrm{CD} 36^{\text {low }}(2 \%)$ and $\mathrm{CD} 34^{\text {neg }} \mathrm{CD} 36^{\text {neg }}(75 \%)$. In semisolid-media, $\mathrm{CD} 34^{\text {pos }} \mathrm{CD} 36^{\text {neg }}$ cells generated BFU-E and CFU-GM (in a $1: 1$ ratio), $C D 34^{\text {neg }} C D 36^{\text {neg }}$ cells mostly BFU-E $(87 \%)$ and $C D 34^{\text {pos }} C D 36^{\text {pos }}$ and $C D 34^{\text {neg }} C D 36^{\text {low }}$ cells were not tested due to low numbers. Under HEMA conditions, CD34 ${ }^{\text {pos }} C D 36^{\text {neg }}, C D 34^{\text {pos }} C D 36^{\text {pos }}, C D 34^{\text {neg }} C D 36^{\text {low }}$ and $\mathrm{CD} 34^{\text {neg }} \mathrm{CD} 36^{\text {neg }}$ cells generated EBs with fold-increases of $\approx 9,000,100,60$ and 1 , respectively, and maturation times (day with $>10 \%$ CD $36^{\text {high }} \mathrm{CD} 235 \mathrm{a}^{\text {high }}$ cells) of $10-7$ days. Pyrenocytes were generated only by CD $34^{\text {neg }} / \mathrm{CD} 36^{\text {neg }}$ cells by day 15 . These results confirm that the majority of HPC in AB express CD34 but identify additional CD34 $4^{\text {neg }}$ populations with erythroid differentiation potential which, based on differences in fold-increase and maturation times, may represent a hierarchy of HPC present in AB.
\end{abstract}

\section{Introduction}

Hematopoiesis is defined as the orderly sequence of events that replenishes the cellular elements of the blood on a daily basis [1]. Under steady-state conditions, the bone marrow provides the microenvironmental cues that allow hematopoietic stem cells to generate a hierarchy of cells (the hematopoietic progenitor cells, HPCs) progressively more restricted in their proliferation and lineage maturation potential [2]. In addition, bone marrow contains very rare precursor cells with the potential to generate hematopoietic stem cells [3]. Human stem cell precursors and stem cells are functionally defined by surrogate assays in animal models [4], while HPCs with different proliferation/maturation potential are defined by semisolid cultures that model the hematopoietic process in vitro [5]. These functional in vitro assays provided the basis for the identification and prospective isolation of a hierarchy of different hematogenic populations present in bone marrow [6]. Based on number and lineage of the cells generated and of the time required for their generation, semisolid assays identify a series of HPCs: HPCs able to generate large colonies ( $>30,000$ cells) comprising cells of multiple lineages (the colony-forming unit, granulocyticerythroid-megakaryocitic-monocytic, CFU-GEMM) by day 15-18, those which generate erythroid bursts (approximately 5,000 cells, burst-forming unit erythroid BFU-E) and granulomonocytic colonies (colony forming unit, granulomonocytic, CFU-GM) by day 12-15, and finally those which generate clusters (50-200 cells) composed only by erythroid (colony-forming unit, erythroid, CFU-E), granulocytic (CFU-G) or monocytic (CFU-M) cells by day 8 [5].

CD34 is an antigen expressed by HPCs of all types whose expression is lost at the CFU-E level $[5,6]$. CFU-GEMM express also CD38 but do not express the $\alpha$ subunit of 
the interleukin-3 (IL-3) receptor, which is acquired during the transition of these cells to BFU-E, CFU-GM, and CD45RA $[7,8]$, which is specifically expressed by BFU-E $[5,6]$. CD36 is an antibody that recognizes thrombospondin, the receptor for the malarial parasite whose expression is activated within a few hours of exposure to erythropoietin (EPO) [9]. Although it is conceivable that CD36 is expressed by erythroid cells of all types, how its expression is modulated during the transition from CFU-GEMM to CFU-E is not known. HPCs may egress from the bone marrow into the circulation [2]. However, since maturation alters the adhesion receptor profile of the cells and their affinity for the marrow niches, HPCs are released from the marrow with different efficiencies and their frequency in blood may not correspond to that of the marrow [10]. The majority of erythroid HPCs in the marrow are CFU-E, but the majority (>90\%) of those in blood are BFU-E [11].

The HPCs present in adult peripheral blood (AB) are discarded during the leukoreduction process used to prepare red blood cells for transfusion. Discarded AB HPCs are used in several liquid culture systems to generate great numbers of lineage-restricted precursors to study hematopoiesis $[12,13]$. More recently, it has been realized that AB HPCs discarded in the buffy coat from a single donation cultured in the presence of dexamethasone (DXM) and estradiol (ES), and in addition to stem cell factor (SCF), IL-3 and EPO (human erythroid massive amplification, HEMA, culture) [14] may generate erythroblasts (EBs) in numbers sufficient for 3-50 transfusions [15], paving the way for an important area of translational medicine: production of alternative transfusion products ex vivo. Although both $\mathrm{AB}$ mononuclear (MNC) and $\mathrm{CD} 34^{\text {pos }}$ cells generate great numbers of EBs in HEMA culture, the total number of erythroid cells generated by CD34 $4^{\text {pos }}$ cells is on average 1-log lower than that generated by MNC [13]. This observation has been ascribed to loss of HPCs with erythroid differentiation potential (erythroid precursor cells, EPC) during the CD34 selection procedure and/or to the existence of circulating $\mathrm{CD} 34^{\text {neg }}$ EPC. The second hypothesis is supported by a recent report indicating that $\mathrm{AB} C D 34^{\text {neg }}$ cells may differentiate into $\mathrm{EBs}$ under HEMA conditions generating more EBs than the corresponding CD34 $4^{\text {pos }}$ cells [16]. The phenotype of the CD34 ${ }^{\text {neg }}$ cells with erythroid potential present in $A B$ buffy coats is not known.

The aim of our study was to further clarify the phenotype of the HPCs/EPC present in AB MNC and to evaluate their contribution to the generation of EBs under HEMA conditions. Flow cytometric profiling for CD34 and CD36 expression of $\mathrm{AB} \mathrm{MNC}$ followed by functional characterization (colony-forming ability in semisolid media and fold increase in HEMA) of the prospectively isolated populations was perfomed. The results presented indicate that CD34/CD36 profiling identifies a hierarchy of $\mathrm{EPC}$ in $\mathrm{AB}$.

\section{Materials and Methods}

2.1. Human Subjects. Peripheral blood was collected from 10 normal adult donors at the transfusion center of
"La Sapienza" University (Rome, Italy) according to guidelines established by institutional ethical committees.

2.2. Cell Separation. Mononuclear cells (MNCs) were separated by centrifugation over Ficoll-Hypaque (Amersham Pharmacia Biotec, Uppsala, Sweden). MNC were first antigenically profiled for CD34/CD36 expression by standard flow cytometric techniques and MNC populations with different CD34/CD36 profiles subsequently separated by a combination of magnetic bead separation and sorting as described in Figure 1. For flow cytometrical profiling, MNC were suspended in $\mathrm{Ca}^{2+} \mathrm{Mg}^{2+}$-free phosphate-buffered saline, supplemented with $1 \% \mathrm{BSA}, 2 \mathrm{mmol} / \mathrm{L}$ ethylenediamine tetraacetate (EDTA), and $0.01 \% \mathrm{NaN} 3$, stained with either allophycocyanin- (APC-) conjugated CD36, phycoerythrin(PE-) conjugated CD14 (monocyte differentiation antigen 14 antibody), or fluorescein isothiocyanate- (FITC-) conjugated CD42a (which recognize GPIb) [17], or appropriate isotype controls (all from Becton Dickinson Biosciences, Franklin Lakes, NJ, USA) and analyzed with the FACS Aria (Becton Dickinson Biosciences) equipped with three air-cooled and solid-state lasers (488-nm, 633-nm, and 407-nm). Dead cells were excluded by SYTOX Blue $(0.002 \mathrm{mM}$, Molecular Probes, Carlsband, Calif, USA) staining. MNC were then divided into $\mathrm{CD} 34^{\text {pos }}$ and $\mathrm{CD} 34^{\text {neg }}$ populations using Magnetic MultiSort Microbeads (Miltenyi Biotec, Bergisch Gladbach, Germany). The CD34 pos fraction was further divided into $\mathrm{CD} 36^{\text {neg }}$ and $\mathrm{CD} 36^{\text {pos }}$ by sorting with the FACS Aria. The $\mathrm{CD} 34^{\text {neg }}$ fraction was enriched for $\mathrm{CD} 36^{\text {pos }}$ and $\mathrm{CD} 36^{\text {neg }}$ cells with Magnetic MultiSort Microbeads coated with CD36. All the bead-based cell enrichments were performed as described by the manufacturer. $\mathrm{CD} 36^{\text {pos }}$ cells were further divided into $\mathrm{CD} 36^{\text {low }}$ and $\mathrm{CD} 36^{\text {high }}$ by sorting. Whenever the cell number allowed, the purified populations were reanalyzed for purity and found $>90 \%$ pure. Results were analyzed by BD FACSDiva Software version 5.0.3.

2.3. Colony-Forming Assay. The colony forming ability of unfractionated and sorted cells was evaluated in standard semisolid methylcellulose cultures (40\%, Fluka Biochemika) stimulated with human SCF (10 ng/mL), IL-3 (10 ng/mL), granulocyte-macrophage colony-stimulating factor (GMCSF, $10 \mathrm{ng} / \mathrm{mL}$ ), granulocyte colony-stimulating factor (GCSF, $100 \mathrm{ng} / \mathrm{mL})$ and EPO $(5 \mathrm{U} / \mathrm{mL})$ [18]. The cultures were incubated at $37^{\circ} \mathrm{C}$ in a fully humidified $5 \% \mathrm{pCO}_{2}$ atmosphere and scored after 14 days for the growth of hematopoietic colonies. CFU-GEMM-, BFU-E-, and CFU-GM-derived colonies were recognized according to standard morphological criteria $[18,19]$.

2.4. Ex Vivo Expansion of Human EBs under HEMA Conditions. MNC $\left(10^{6}\right.$ cells $\left./ \mathrm{mL}\right)$ and prospectively isolated cells $\left(5 \times 10^{4}\right.$ cells $\left./ \mathrm{mL}\right)$ were cultured under HEMA conditions, as described [14]. Briefly, the cultures contained Iscove's modified Dulbecco's medium (IMDM, Lonza Group Ltd, Basel, Switzerland) supplemented with fetal bovine serum (FBS, Sigma-Aldrich) $(20 \% \mathrm{v} / \mathrm{v})$, detoxified human serum albumin (HSA) (25\%, Baxter International Inc, Deerfield, 


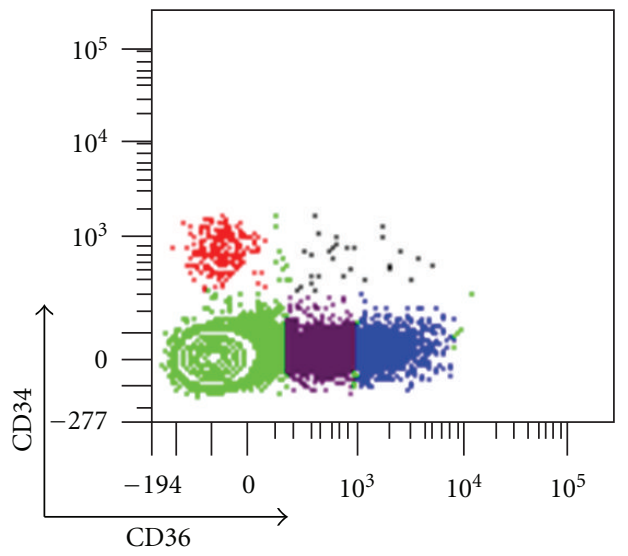

Summary of CD34/CD36 profiling of AB MNC

(a)

\begin{tabular}{|c|c|c|}
\hline & Phenotype & Frequency \\
\hline A & $\mathrm{CD} 34^{\text {pos }} \mathrm{CD} 36^{\text {neg }}$ & $0.1 \pm 0.05 \%$ \\
\hline B & $\mathrm{CD} 34^{\mathrm{pos}} \mathrm{CD} 36^{\mathrm{pos}}$ & Barely detectable- $0.1 \%$ \\
\hline C & $\mathrm{CD} 34^{\text {neg }} \mathrm{CD} 36^{\text {low }}$ & $2 \pm 0.8 \%$ \\
\hline $\mathrm{D}$ & CD34 $4^{\text {neg }} C D 36^{\text {high }}$ & $1 \pm 0.6 \%$ \\
\hline E & $\mathrm{CD} 34^{\text {neg }} \mathrm{CD} 36^{\text {neg }}$ & $74.3 \pm 21.8 \%$ \\
\hline
\end{tabular}

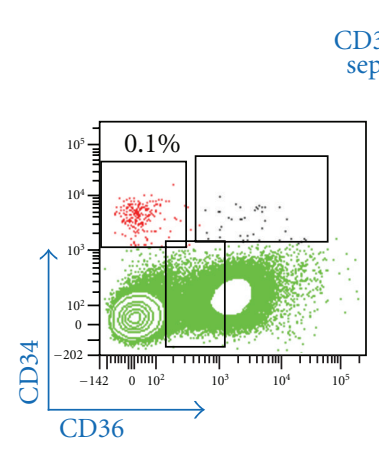

CD34 MACs separation
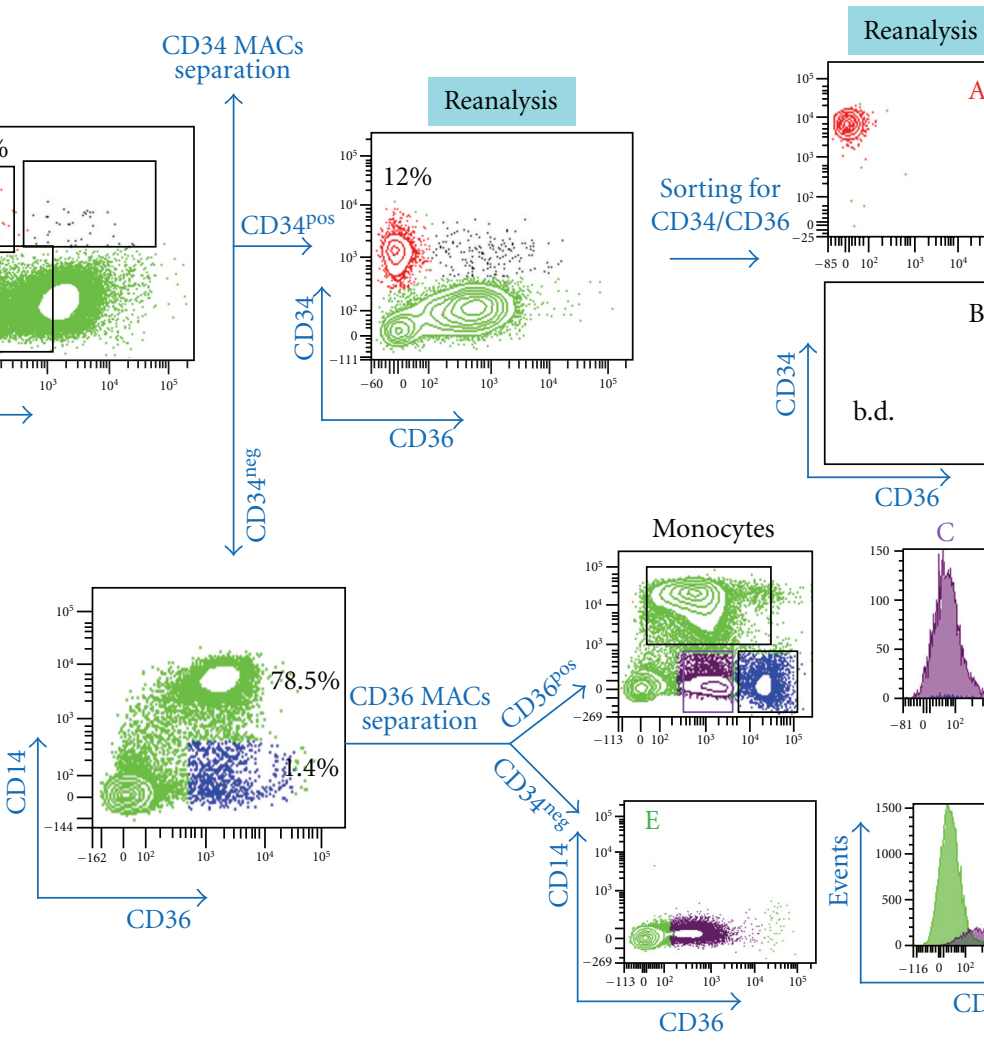

Monocytes
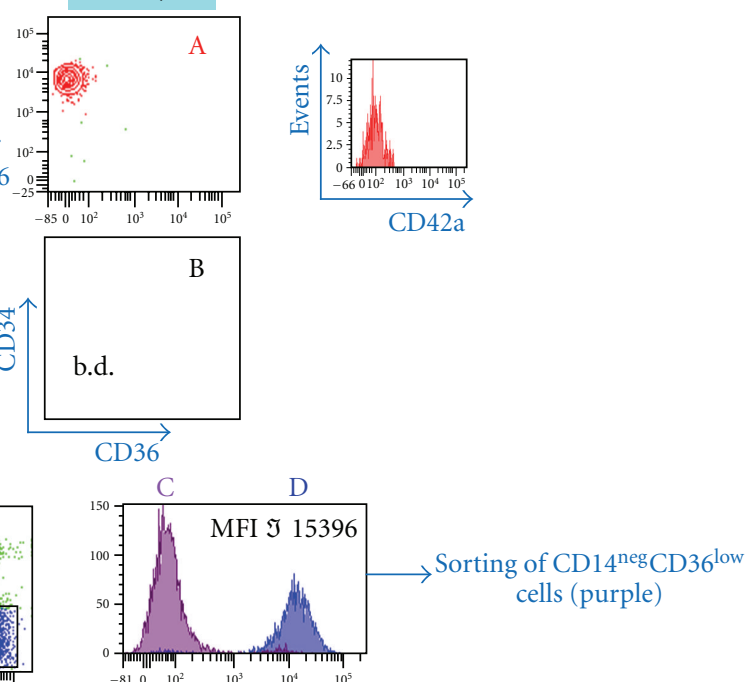

(b)

Figure 1: CD36/CD34 expression profiling of AB MNC. (a) Representative coulter plot analyses for CD36/CD34 expression of MNC from a representative $\mathrm{AB}$ and summary of the frequency of the different populations identified by this analyses. CD36/CD34 profiling identified five populations: $\mathrm{CD} 34^{\text {pos }} \mathrm{CD} 36^{\text {neg }}$ cells (population A, red), $\mathrm{CD} 34^{\text {pos }} \mathrm{CD} 36^{\text {pos }}$ cells (population B, black), and CD34 ${ }^{\text {neg }} \mathrm{CD} 36^{\text {neg }}$ cells (population E, green). A fourth CD34 ${ }^{\text {neg }} \mathrm{CD} 36^{\text {pos }}$ population contained numerous CD14 ${ }^{\text {pos }}$ cells which are represented by monocytes (see Figure 1 (b)). Exclusion of these $\mathrm{CD} 14^{\text {pos }}$ cells from the analyses revealed two CD $34^{\text {neg }} / \mathrm{CD} 36^{\text {pos }}$ populations which express $\mathrm{CD} 36$ al low $\left(\mathrm{CD} 34^{\text {neg }} \mathrm{CD} 36^{\text {pos }}\right.$, population $\mathrm{C}$, purple) and high $\left(\mathrm{CD} 34^{\text {neg }} \mathrm{CD} 36^{\text {high }}\right.$ cells, population $\mathrm{D}$, blue) levels, respectively. The table on the right summarizes the mean frequency $( \pm \mathrm{SD})$ of each population among MNC obtained from 3 different donors. All the results presented in this figure and in Figure 2 (a) are presented with the same color code. (b) Prospective isolation of AB MNC on the basis of CD34/CD36 expression. MNC were first divided in two populations enriched or deprived of $\mathrm{CD} 34^{\text {pos }}$ cells by CD34-coated magnetic bead adsorption. The CD34 ${ }^{\text {pos }}$ population was further purified and divided into CD36 ${ }^{\text {neg }}$ and CD36 ${ }^{\text {pos }}$ cells by sorting. The CD34 beads flow-through fraction (enriched for CD34 ${ }^{\text {neg }}$ cells) was further divided into $\mathrm{CD} 36^{\mathrm{pos}}$ and $\mathrm{CD} 36^{\text {neg }}$ cells by magnetic bead isolation. The cells eluted from the beads were purified by sorting on the basis of lack of expression of CD14 and low level of CD36 expression (population C, purple). The CD14 ${ }^{\text {neg }}$ CD $36^{\text {high }}$ cells (population D, blue) were not isolated because expressed high levels of the megakaryocytic marker CD42a. Finally, the CD36 beads flow-through fraction was enriched for $\mathrm{CD} 36^{\text {neg }}$ cells by sorting. These $\mathrm{CD} 36^{\text {neg }}$ cells were also CD34 ${ }^{\text {neg }}$ upon reanalyses (not shown). Whenever feasible, the prospectively isolated cells were reanalyzed for purity. Results are representative of those obtained in 3 independent purifications. 


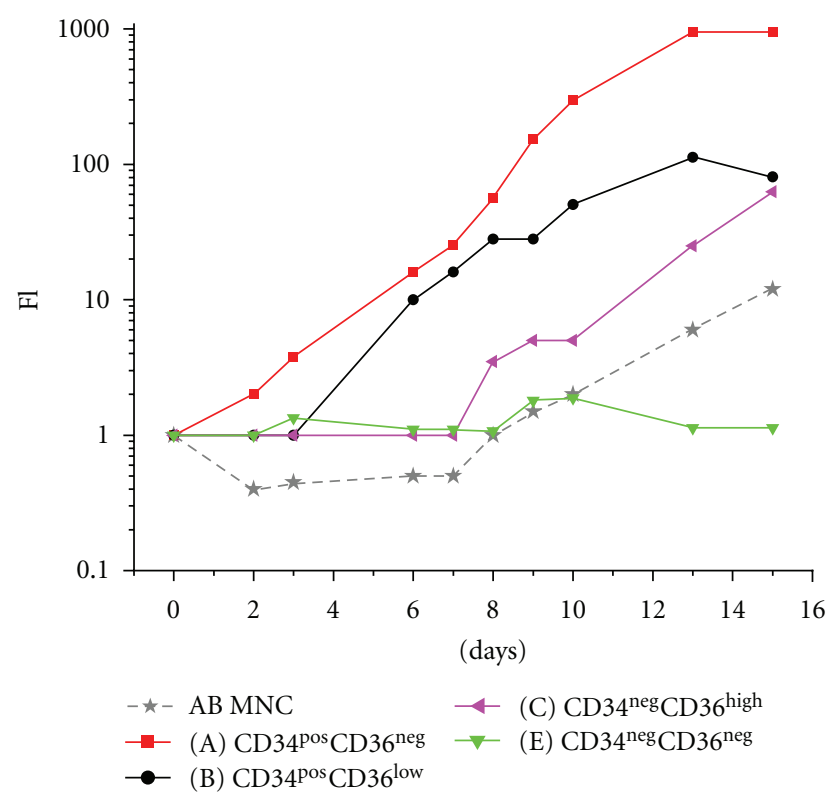

(a)
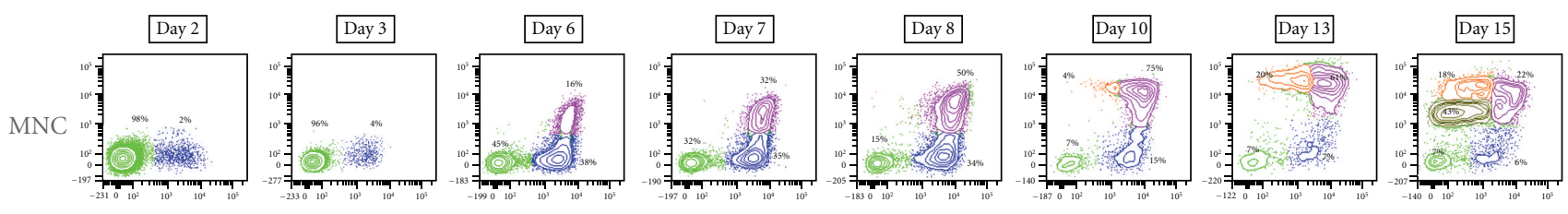

A
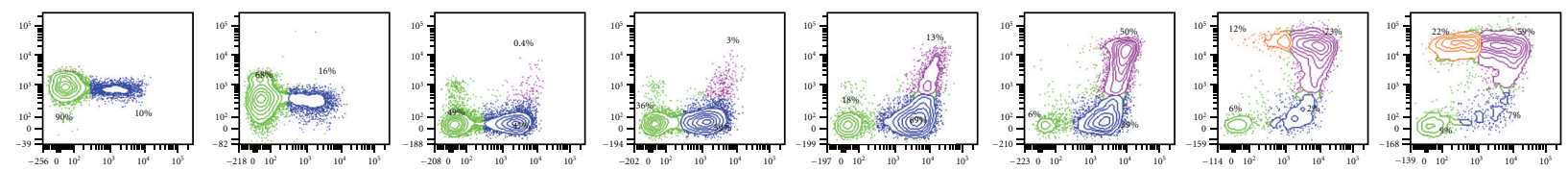

B

nd

C

nd

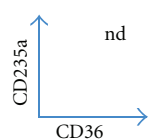

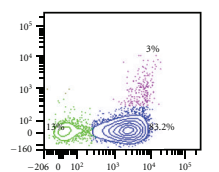
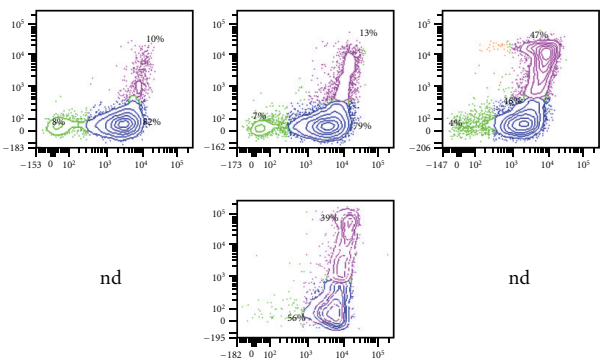

nd
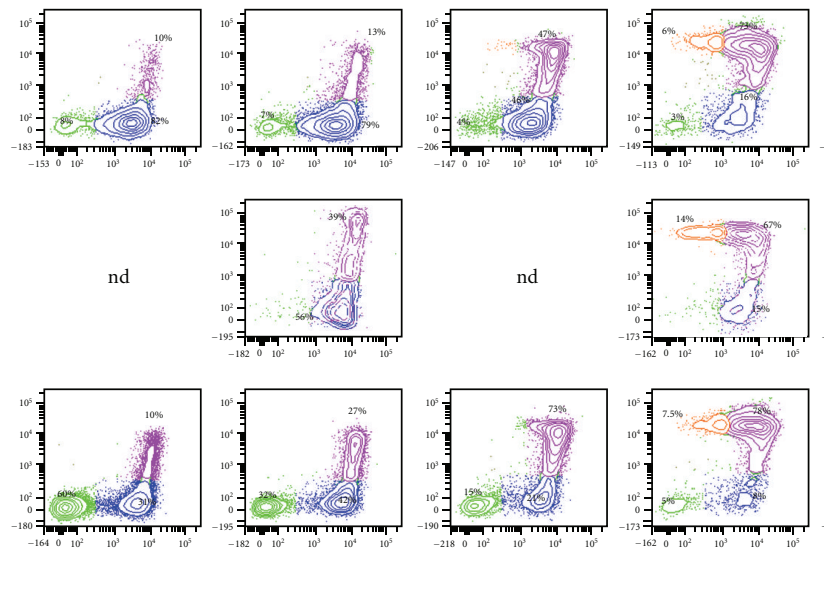

(b)
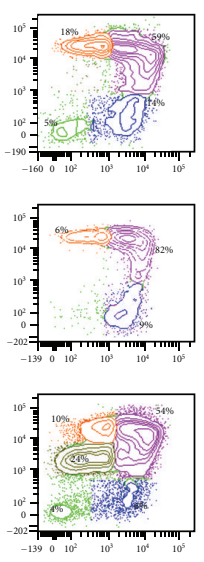

FIGURE 2: Growth and erythroid maturation of MNC prospectively isolated on the basis of CD34/CD36 profiling under HEMA conditions. (a) Growth curve of cells prospectively isolated from AB MNC under HEMA conditions (the same color code as in Figure 1). MNC (grey dotted line) were cultured in parallel as control. The number of cells present in the cultures is expressed as fold increase (FI). Results from a representative experiment are shown. Similar results were observed in 2 additional experiments (see also Table 1). (b) Time course of the maturation of EBs in HEMA cultures seeded with either $\mathrm{AB} \mathrm{MNC}$ or with populations $\mathrm{A}, \mathrm{B}, \mathrm{C}$, or E, as indicated. EBs maturation was defined on the basis of CD36/CD235a profiling which divides EBs into three populations: $C D 36{ }^{\text {pos }} \mathrm{CD} 235 \mathrm{a}^{\text {neg/low }}$ (proerythroblasts, blue); $\mathrm{CD} 36^{\text {pos }} / \mathrm{CD} 235 \mathrm{a}^{\text {med/high }}$ (basophilic erythroblasts, purple), and CD $36^{\text {low }} \mathrm{CD} 235 \mathrm{a}^{\text {high }}$ (orthochromatic erythroblasts, red). Forward and side scatter analyzes identified a fourth population of small CD $36{ }^{\text {low }} \mathrm{CD} 235 \mathrm{a}^{\text {low }}$ cells, probably represented by pyrenocytes (yellow). Cells which do not express EB markers are indicated in green. The numbers within each quadrant indicate the frequency of the different subpopulations. Results are representative of those obtained in three independent experiments. nd = not done, due to low cell numbers. 
TABLE 1: Summary of the number of cells recovered in each fraction after CD36/CD34-based purification and of their growth in HEMA culture. Results with MNC and population A are presented as mean $( \pm \mathrm{SD})$ of those obtained in three separate experiments. Results with population $\mathrm{E}$ are representative of two independent experiments, while a complete data set for populations B and C is available only from one experiment.

\begin{tabular}{|c|c|c|c|c|c|}
\hline & Cell population & $\begin{array}{l}\text { Cells obtained } \\
\text { from1 buffy coat }\end{array}$ & Recovery $(\%)^{*}$ & $\begin{array}{l}\text { FI in HEMA } \\
\text { (Day 14) }\end{array}$ & $\begin{array}{c}\text { Total theoretical number } \\
\text { of EBs generated in } \\
\text { HEMAat day } 14^{* *}\end{array}$ \\
\hline & MNC & $272( \pm 86) \times 10^{6}$ & $100 \%$ & $10.1 \pm 1.4$ & $2.7 \times 10^{9}$ \\
\hline A & $\mathrm{CD} 34^{\text {pos }} \mathrm{CD} 36^{\text {neg }}$ & $75( \pm 53.5) \times 10^{3}$ & $27.5 \%$ & $9,347 \pm 950$ & $7.0 \times 10^{8}$ \\
\hline B & $\mathrm{CD} 34^{\mathrm{pos}} \mathrm{CD} 36^{\mathrm{pos}}$ & 9,500 & $3.5 \%$ & 113 & $1.1 \times 10^{6}$ \\
\hline C & $\mathrm{CD} 34^{\text {neg }} \mathrm{CD} 36^{\text {low }}$ & 7,500 & $1.4 \times 10^{-3} \%$ & 62.5 & $5.0 \times 10^{5}$ \\
\hline $\mathrm{E}$ & $\mathrm{CD} 34^{\text {neg }} \mathrm{CD} 36^{\text {neg }}$ & $2-10 \times 10^{6}$ & $1.0-4.9 \%$ & $1.14-3.5$ & $0.2-3.5 \times 10^{7}$ \\
\hline
\end{tabular}

* Recovery was calculated by dividing the total number of cells obtained after the purification per the theoretical number of cells present in MNC. The theoretical cell number of each fraction was calculated by multiplying the frequency of the population, presented in Figure 1(a), per the average number of MNC obtained from an AB buffy coat $\left(272 \times 10^{6}\right)$.

**The theoretical total number of EBs obtainable at day 14 from each fraction was calculated by multiplying the total cell number of the fraction per the corresponding FI.

iLL, USA) [15], human SCF (50 ng/mL, Sigma-Aldrich), EPO (3 U/mL, Neorecormon, Auckland, New Zealand) and IL-3 (10 ng/mL, Biosource, San Jose, Calif, USA), DXM $\left(10^{-6} \mathrm{M}\right)$ and ES $\left(10^{-6} \mathrm{M}\right)$ (both from Sigma-Aldrich), Lglutamine $(200 \mathrm{mM}$, Euroclone SpA, Siziano, Italy), antibiotics [penicillin ( 10,000 units $/ \mathrm{mL})$, streptomycin sulfate $(10,000 \mu \mathrm{g} / \mathrm{mL})$, fungizone $(25 \mu \mathrm{g} / \mathrm{mL})$, Lonza Group Ltd], and $\beta$-mercaptoethanol $\left(10^{-6} \mathrm{M}\right)$. The cultures were kept for up to $10-15$ days at $37^{\circ} \mathrm{C}$ and $5 \% \mathrm{pCO}_{2}$ in a fully humidified incubator.

2.5. Cell Viability, Phenotypic Analysis and Sorting. Cell numbers and viability were assessed by microscopic evaluation after trypan blue (Boston Bioproducts, Ashland, Mass, USA) staining. For flow cytometrical characterization, cells were suspended in $\mathrm{Ca}^{2+} \mathrm{Mg}^{2+}$-free phosphate-buffered saline, supplemented with $1 \% \mathrm{BSA}, 2 \mathrm{mmol} / \mathrm{L}$ ethylenediamine tetraacetate (EDTA), and $0.01 \% \mathrm{NaN} 3$, stained with either allophycocyanin- (APC-) conjugated CD36 or phycoerythrin- (PE-) conjugated CD235a (antiglycophorin A), or appropriate isotype controls (all from Becton Dickinson Biosciences) and analyzed with the FACS Aria. Dead cells were excluded by SYTOX Blue $(0.002 \mathrm{mM}$, Molecular Probes) staining. Forward and side scatter analyses of cells expressing the mature $\mathrm{CD} 36^{\text {low }} \mathrm{CD} 235 \mathrm{a}^{\text {high }}$ phenotype and of small size were used for the identification of pyrenocytes [20].

2.6. Statistical Analysis. Results are presented as mean $( \pm \mathrm{SD})$ of those obtained in at least three experiments per data set. Mean $( \pm$ SD) were calculated with the computer software Origin 5.0 for Windows (Microcal Software, Inc., Northampton, Mass, USA).

\section{Results}

3.1. Antigenic Profiling of $A B M N C$. CD34/CD36 profiling divided $\mathrm{AB}$ MNC into 4 populations: $\mathrm{CD} 34^{\text {pos }} \mathrm{CD} 36^{\text {neg }}$ (population A, $0.1 \pm 0.05 \%$ ), $\mathrm{CD} 34^{\text {pos }} \mathrm{CD} 36^{\text {pos }}$ (population $\mathrm{B}$, often present in barely detectable numbers but reaching in some donors a frequency of $\sim 0.1 \%), \mathrm{CD} 34^{\mathrm{neg}} \mathrm{CD} 36^{\mathrm{pos}}$ $(\sim 23 \%)$ and $\mathrm{CD} 34^{\text {neg }} \mathrm{CD} 36^{\text {neg }}$ (population E, $\sim 74 \%$ ) (Figure $1(\mathrm{a})$ ). $\mathrm{CD} 34^{\text {neg }} \mathrm{CD} 36^{\text {pos }}$ cells could in turn be divided into three populations: the majority of them expressed CD14 and was, therefore, represented by monocytes (monocytes are known to express CD36) [21] (Figure 1(b)). By dot blot distribution and CD42a staining, the remaining could be divided into two additional populations: $\mathrm{CD} 34^{\text {neg }} \mathrm{CD} 36^{\text {low }}$ (population $\mathrm{C}, \sim 2 \%$ ), which does not express CD42a, and $\mathrm{CD} 34^{\text {neg }} \mathrm{CD} 36^{\text {high }}$ (population $\mathrm{D}, \sim 1.0$ ), which express high levels of CD42a (mean fluorescence intensity, MFI > 15, 000) (Figure 1(b)).

\subsection{Prospective Isolation of MNC Populations Based on CD34} and CD36 Expression. $\mathrm{AB}$ MNCs were purified on the basis of CD34 and CD36 expression by the combination of magnetic bead enrichment and cell sorting described in Figure 1(b). First, CD34 ${ }^{\text {pos }}$ cells were enriched by selection with CD34-coated microbeads. The CD34 pos fraction $(12 \%$ pure by reanalyses) was then sorted into $\mathrm{CD} 34^{\text {pos }}$ cells expressing $\left(\mathrm{CD} 36^{\mathrm{pos}}\right.$, A population $)$ or not $\left(\mathrm{CD} 36^{\mathrm{neg}}, \mathrm{B}\right.$ population) CD36. Approximately 75,000 A cells and 10,000 $\mathrm{B}$ cells were recovered from the buffy coat of an average donation (Table 1). Population A was $>98 \%$ pure by reanalyses while the purity of population B was not determined due to low cell recovery.

Reanalyses for CD36 and CD14 expression of the flowthrough fraction of the CD34-coated magnetic beads revealed that a great number $(\sim 78 \%)$ of $\mathrm{CD} 36^{\mathrm{pos}}$ cells expressed also CD14. This flow-through fraction was further divided into CD36-enriched and CD36-deprived fractions by CD36-magnetic bead isolation. The cells adsorbed to the beads which did not express CD14 and CD42a and expressed $\mathrm{CD} 36$ at low levels were sorted $\left(\mathrm{CD} 34^{\text {pos }} \mathrm{CD} 36^{\text {low }}\right.$, population C) (Figure 1(b)). Approximately 7,500 C cells were recovered from the buffy coat of a blood donation (Table 1). This low number prevented reanalyses for purity of this cell population and limited its functional characterization. The $\mathrm{CD} 14^{\text {neg }} \mathrm{CD} 34^{\text {neg }}$ cells which expressed CD36 at high levels 
(CD34 ${ }^{\text {neg }} \mathrm{CD} 36^{\text {high }}$, population D) was not sorted because of its high CD42a expression, which suggest that the may have been represented by megakaryocytic precursors [17].

The flow-through fraction of the CD36 magnetic beads was further purified by sorting (population E). A total of 10 million $\mathrm{CD} 34^{\text {neg }} \mathrm{CD} 36^{\text {neg }}$ cells were recovered from an average $\mathrm{AB}$ buffy coat (Table 1 ).

\subsection{Cloning Efficiency of $A B$ Populations Prospectively Isolated} on the Basis of CD34/CD36 Profiling. The progenitor cell activity in semisolid assays of population $\mathrm{A}$ and $\mathrm{E}$ is presented in Table 2. AB MNC were analyzed in parallel as control. As expected, population A was greatly enriched for colony forming cells (cloning efficiency 16\%) and generated both BFU-E- and CFU-GM-derived colonies (in a 1:1 ratio). It also contained few (0.001\%) CFU-GEMM. By contrast, population $\mathrm{E}$ had a cloning efficiency $40 \%$ lower than that of MNC and generated mainly (80\%) erythroid bursts. No difference in size and morphology was observed among erythroid bursts originated from population $\mathrm{A}$ and $\mathrm{E}$ and $\mathrm{MNC}$ (insert in Table 1), an indication that the BFU-E present in the different fractions had similar proliferation/maturation potential.

3.4. Expansion Potential under HEMA Conditions of AB Populations Prospectively Isolated on the Basis of CD34/CD36 Profiling. The expansion potential under HEMA conditions of $\mathrm{AB}$ populations prospectively isolated on the basis of CD34/ CD36 profiling is compared in Figure 2(a) and Table 1. $\mathrm{AB} \mathrm{MNC}$ were analyzed in parallel as control. As expected, under HEMA conditions, population A had great proliferation potential expressing FIs between 900 (Figure 2(a)) and 24,000 (average FI $=9,000$, Table 1 ) compared to FI < 10 of the corresponding MNC. Significant numbers of cells were also generated by population $\mathrm{B}$ and $\mathrm{C}$ which expressed FI of 100 and 60 by day 13 (Figure 2(a) and Table 1). By contrast, population E had FI as low as 1-3. However, given the great numbers of cells segregating in this fraction $\left(>10^{7}\right)$, population E generated many cells $\left(\sim 10^{7}\right)$ under HEMA conditions $(\mathrm{FI} \sim 1)$.

3.5. Maturation Potential of AB MNC Populations Prospectively Isolated on the Basis of CD34/CD36 Profiling. The lineage and maturation stage of the progeny of $A B M N C$ and of $A B$ populations prospectively isolated on the basis of CD36/ CD34 profiling is presented in Figure 2(b). EBs maturation was defined on the basis of CD36/CD235a profiling which divides EBs into three populations: $\mathrm{CD} 36^{\mathrm{pos}} \mathrm{CD} 235 \mathrm{a}^{\text {neg/low }}$ (pro-erythroblasts); CD36 ${ }^{\text {pos }} / \mathrm{CD} 235 \mathrm{a}^{\mathrm{med} / \mathrm{high}}$ (basophilic erythroblasts), CD $36{ }^{\text {low }} \mathrm{CD} 235 \mathrm{a}^{\text {high }}$ (orthochromatic erythroblasts) [5]. A fourth population of $\mathrm{CD} 36{ }^{\text {low }} \mathrm{CD} 235 \mathrm{a}^{\text {low }}$ cells with low forward and side scatter is composed by pyrenocytes [20].

In cultures of MNC, cells with an immature EBs phenotype (CD36 ${ }^{\text {pos }} \mathrm{CD} 235 \mathrm{a}^{\text {neg }}$ ) became detectable very quickly ( $2 \%$ by day 2 ) while non-EBs became detectable in modest numbers (6-7\%) by day 10. Mature EBs (CD36 ${ }^{\text {pos }}$ CD235a ${ }^{\text {pos }}$ ) were detected by day $6(15 \%)$ and reached a frequency $>70 \%$ by day 10 . By day 15 , immature EBs became barely detectable and numerous cells with $\mathrm{CD} 366^{\text {low }} \mathrm{CD} 235 \mathrm{a}^{\text {high }}$ phenotype (both larger cells corresponding to orthochromatic EBs, $18 \%$, and smaller cells corresponding to pyrenocytes, $40 \%$ ) were detected (Figure 2(b)).

In HEMA cultures of population A, immature EBs were also detected very early ( $10 \%$ by day 2$)$ but the frequency of mature EBs reached $10 \%$ only by day 8 . By day 15 , the cultures contained significant numbers $(22 \%)$ of CD36 $6^{\text {low }} /$ CD235ahigh orthochromatic EBs but no pyrenocytes (Figure 2(b)).

In HEMA culture of population B, numbers of cells sufficient for antigenic profiling were obtained by day 6 . $\mathrm{CD} 36^{\text {pos }} \mathrm{CD} 235 \mathrm{a}^{\text {neg }}$ cells represented the majority $(\sim 83 \%)$ of the cells from day 6 to day 8 . In these cultures, mature CD $36{ }^{\text {pos }} \mathrm{CD} 235 \mathrm{a}^{\text {pos }}$ EBs were observed at earlier time points with respect to cultures of population A (3\% and $10 \%$ of CD $36^{\text {pos }} \mathrm{CD} 235 \mathrm{a}^{\text {pos }}$ cells by day 6-7 versus day 7-8 in cultures of population B and A, resp.) (Figure 2(b)). By day 15, the maturation phenotype of the progeny of population $B$ and $A$ was the same.

HEMA cultures of population $\mathrm{C}$ were originally seeded with number of cells comparable to those used for population $\mathrm{A}$ and $\mathrm{B}(\sim 7,500$ cells with respect to $9,500-$ 10,000 cells used for the two other populations). However, cultures of population C grew very slow (see Figure 2(a)) and the number of cells reached values sufficient for antigenic profiling only by day 8 . At day 8 , great numbers (39\%) of the EBs had already the mature CD36 ${ }^{\text {pos }} / \mathrm{CD} 235 a^{\text {high }}$ phenotype. However, the progeny of population $\mathrm{C}$ progressed poorly to the orthochromatic stage and only $6 \%$ of them had acquired the CD36 ${ }^{\text {low }}$ CD $235 a^{\text {high }}$ phenotype by day 15 .

Finally, population E did not generate significant numbers $(26 \%)$ of $\mathrm{CD} 36^{\text {pos }} \mathrm{CD} 235 \mathrm{a}^{\text {neg }}$ cells until day 6 . The cells progressed then very rapidly to the CD $36^{\text {pos }} \mathrm{CD} 235 \mathrm{a}^{\text {high }}$ stage $\left(10 \% \mathrm{CD} 36^{\text {pos }} \mathrm{CD} 235 \mathrm{a}^{\text {high }}\right.$ cells by day 7$)$ and $\mathrm{CD} 36^{\text {low }}$ CD235a high stage $(7.5 \%$ by day 13$)$. Pyrenocytes were detectable in these cultures at levels similar to those observed in cultures of MNC (24\%) by day 15 .

In conclusion, in spite of differences in kinetics, all the populations analyzed in this study generated EBs under HEMA conditions.

\section{Discussion}

CD36/CD34 profiling identifies at least four populations present in $\mathrm{AB}$ MNC capable to generate colonies in semisolid assay and EBs under HEMA conditions.

In semisolid assay, only $9 \%$ of the original HPCs activity was recovered among the purified fractions (8.1\% in population $\mathrm{A}$ and $0.8 \%$ in population $\mathrm{B})$. Although the cloning efficiency of population $\mathrm{B}$ and $\mathrm{C}$ is not known, given the low cell content of these populations $(\sim 15,000$ cells in total, Table 1 ), they may contain at most $5 \%$ of the MNC HPCs activity. Therefore, $>80 \%$ of the HPCs activity present in the $\mathrm{MNC}$ was lost during the purification procedure. This result suggests the hypothesis that some of the HPCs activity of the MNC is due to pre-HPCs cells which became HPCs in 
TABLE 2: Cloning efficiency of $\mathrm{AB}$ MNC and $\mathrm{AB}$ cell populations prospectively isolated on the basis of CD34/CD36 expression. Results are presented as mean $( \pm \mathrm{SD})$ of those observed in three independent experiments. The inserts present the morphology of a representative BFU-E-derived colony obtained in the corresponding semisolid culture (original magnification 10x).

\begin{tabular}{|c|c|c|c|c|c|c|c|}
\hline & \multirow[b]{2}{*}{ Cell population } & \multicolumn{4}{|c|}{ CFC/plate } & \multirow{2}{*}{$\begin{array}{l}\text { Total CFC } \\
\text { per fraction* }\end{array}$} & \multirow{2}{*}{ Recovery } \\
\hline & & BFU-E & & CFU-GM & CFU-GEMM & & \\
\hline & $\begin{array}{c}\text { MNC } \\
\left(10^{5} \text { cells } / \text { plate }\right)\end{array}$ & & $71 \pm 24$ & $41 \pm 9$ & $1 \pm 1$ & $3.1 \times 10^{5}$ & $100 \%$ \\
\hline A & $\begin{array}{c}\text { CD34 } 4^{\text {pos }} \text { CD } 36^{\text {neg }} \\
\text { (500 cells/plate) }\end{array}$ & & $92 \pm 5$ & $75 \pm 5$ & $0.5 \pm 0.5$ & $2.5 \times 10^{4}$ & $8.1 \%$ \\
\hline E & $\begin{array}{c}\mathrm{CD} 34^{\text {neg }} \mathrm{CD} 36^{\text {neg }} \\
\left(10^{5} \text { cells/plate }\right)\end{array}$ & & $34 \pm 12$ & $8 \pm 3$ & $2 \pm 1$ & $2.4 \times 10^{3}$ & $0.8 \%$ \\
\hline
\end{tabular}

*The total number of CFC per fraction was calculated by multiplying the frequency of CFC (BFU-E + CFU-GM + CFU-GEMM) per the total number of cells in the fraction presented in Table 1.

semisolid assay in response to factors released by accessory cells.

Consistent with the data reported by van den Akker et al. [16], we determined that under HEMA conditions EBs are generated both by $\mathrm{CD} 34^{\text {pos }}$ and $\mathrm{CD} 34^{\text {neg }} \mathrm{AB}$ cells (Table 1 ). Therefore, both populations contain EPC. CD34CD36 profiling identified that in addition to two $\mathrm{CD} 34^{\text {pos }} \mathrm{EPC}$ populations $\left(\mathrm{CD} 34^{\text {pos }} \mathrm{CD} 36^{\text {neg }}\right.$ and $\left.\mathrm{CD} 44^{\text {pos }} \mathrm{CD} 36^{\text {pos }}\right), \mathrm{AB}$ MNC contain $2 \mathrm{CD} 34^{\text {neg }}$ EPC population $\left(\mathrm{CD} 34^{\text {neg }} \mathrm{CD} 36^{\text {low }}\right.$ and $\left.\mathrm{CD} 34^{\text {neg }} \mathrm{CD} 36^{\text {neg }}\right)$. The antigenic profile which defines the $\mathrm{CD} 34^{\text {neg }} \mathrm{CD} 36^{\text {neg }}$ population is still to be identified, although preliminary results indicate that these cells may express CD44 [22], the receptor for hyaluronic acid which interacts also with osteopontin and collagen [23] (data not shown).

By contrast with the great loss of colony forming cells observed with the purification of $\mathrm{AB}$ MNC (Table 2), the purification procedures did not lead to great losses of EPC, as indicated by the observation that the sum of the numbers of EBs generated by the four purified fractions is only modestly $\left(7.5 \times 10^{8}\right.$ versus $\left.2.7 \times 10^{9}\right)$ lower than that generated by MNC (Table 1). Under HEMA conditions, the population which generated the greatest numbers of EBs was population A, only $27 \%$ of which had been recovered during the purification procedures (Table 1). Cultivation under HEMA conditions of a population A containing all the $\mathrm{CD} 34^{\text {pos }} \mathrm{CD} 36^{\text {neg }}$ cells present in one donation $(100 \%$ recovery) would generate as many as $2.3 \times 10^{9} \mathrm{EBs}$, a number very similar to that observed in cultures of MNC. These data indicate cell loss during the purification procedure, rather than great EBs generation by $\mathrm{CD} 34^{\text {neg }}$ HPCs, as the main reason for the overall greater output of EBs from MNC than from CD34 ${ }^{\text {pos }}$ cells in HEMA culture.

Based on FI and on the time required to mature in culture, the four EPC populations identified in $\mathrm{AB}$ were classified according to the hierarchical model presented in Figure 3. $\mathrm{CD} 34^{\text {pos }} \mathrm{CD} 36^{\text {neg }}$ cells may represent earlier cells, probably HPCs (they contain both BFU-E and CFU-GM), while $\mathrm{CD} 34^{\text {pos }} \mathrm{CD} 36^{\text {pos }}$ and $\mathrm{CD} 34^{\text {neg }} \mathrm{CD} 36^{\text {pos }}$ cells may represents early and late erythroid restricted progenitor cells (EPC), respectively. It is possible that these cell populations are linked in a mother-daughter relationship. It is difficult to classify population $\mathrm{E}$ in this model. Since the majority of the cells in this population is likely represented by differentiated precursors, it is conceivable that the progenitor cells represent in this fraction are a rare population with such a great proliferation potential to express FI $=1$. This hypothesis is also supported by the observation that population $\mathrm{E}$ was the slowest population to generate EBs $\left(\mathrm{CD} 36^{\mathrm{pos}} \mathrm{CD} 235 \mathrm{a}^{\mathrm{pos}}\right.$ cells were not detected before day 6). It is suggested that this population may contain precursor cells which are capable to generate $\mathrm{CD} 34^{\text {pos }}$ cells. Further studies involving time course analyses of the expression of CD34 among the progeny of $\mathrm{CD} 34^{\text {neg }} \mathrm{CD} 36^{\text {neg }} \mathrm{E}$ cells are required to clarify this important point. Since the growth factors used to stimulate HEMA culture were selected for optimal EB, and not CD34 cell, generation [15], it is possible that preculture of $\mathrm{CD} 34^{\text {neg }} \mathrm{CD} 36^{\text {neg }} \mathrm{E}$ cells under conditions which promote CD34 cell proliferation (using growth factor combinations including FLT3 ligand or thrombopoietic) [24, 25], will allow generation of greater numbers of EBs when the progeny of their cells will be in turn cultured under HEMA conditions. Also intriguing is the observation that population $\mathrm{E}$ is the only purified populations to generate great numbers of pyrenocytes by day 15 , an indication that its progeny underwent significant levels of enucleation in HEMA. The presence of macrophages greatly favors the enucleation process [26]. In HEMA culture, macrophages are present as contaminant in cultures of MNC which routinely generate pyrenocytes by day 15 (Figure $1(\mathrm{~b})$ ). These cells were removed by the purification process from all the other populations which did not generate pyrenocytes by day 15 . Population E, however, although does not contain macrophages $\left(\mathrm{CD} 14^{\text {pos }} \mathrm{CD} 36^{\text {pos }}\right.$ cells) may contain their precursors, which may maturate in culture, favoring enucleation of EBs. Further studies are required to clarify the role of contaminating macrophages, 

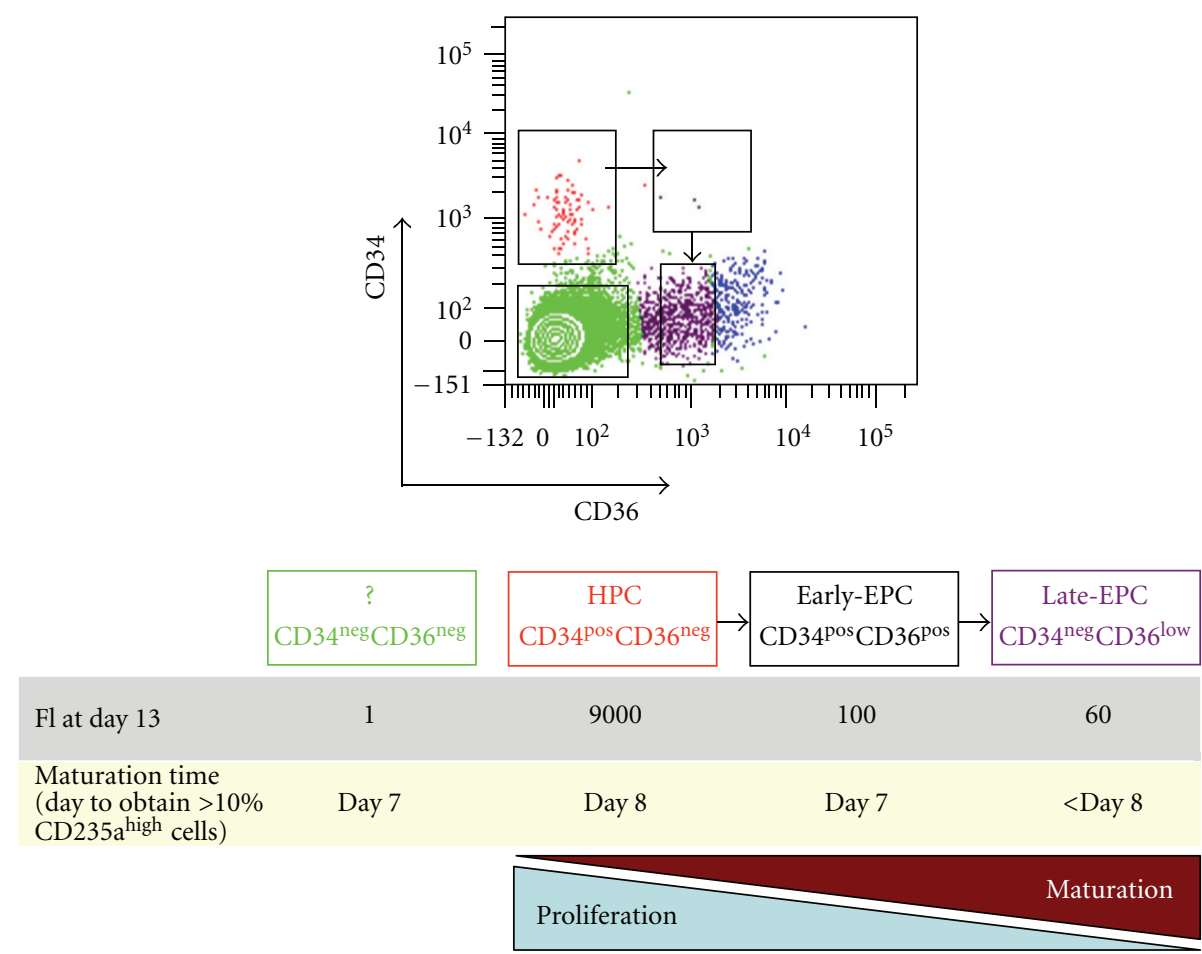

FIGURE 3: A model for the hierarchical relationship between progenitor cells with erythroid proliferation potential present in AB MNC. This model is based of the proliferation potential (as indicated by the FI) and of the speed of maturation (as indicated by the time required to generate significant numbers, $>25 \%$, of mature CD235a $\mathrm{a}^{\text {pos }} \mathrm{EBs}$ ) of the different populations. See text for further details.

and/or of their precursor cells, in the enucleation of human EBs generated under HEMA conditions.

In conclusion, CD34/CD36 profiling identifies a hierarchy of EPC in AB. Although under HEMA conditions the majority of EBs were generated by CD34 ${ }^{\text {pos }}$ cells, it is possible that further improvement of the culture system by favoring proliferation of CD34 ${ }^{\text {neg }}$ cells, may further increase the number of EBs generated by $\mathrm{AB}$.

\section{Funding}

This study was supported by a grant from the NY-STAR foundation (C-06066), from Centro Nazionale Sangue, Rome, Italy, and by institutional funds from the Mount Sinai School of Medicine and Istituto Superiore Sanità, Italy.

\section{References}

[1] S. H. Orkin and L. I. Zon, "Hematopoiesis: an evolving paradigm for stem cell biology," Cell, vol. 132, no. 4, pp. 631-644, 2008.

[2] J. Seita and I. L. Weissman, "Hematopoietic stem cell: self-renewal versus differentiation," Wiley Interdisciplinary Reviews, vol. 2, no. 6, pp. 640-653, 2010.

[3] G. Prindull, "Hemangioblasts representing a functional endothelio-hematopoietic entity in ontogeny, postnatal life, and CML neovasculogenesis," Stem Cell Reviews, vol. 1, no. 3, pp. 277-284, 2005.
[4] J. E. Dick and T. Lapidot, "Biology of normal and acute myeloid leukemia stem cells," International Journal of Hematology, vol. 82, no. 5, pp. 389-396, 2005.

[5] T. Papayannopoulou, J. Abkowitz, A. D’Andrea et al., "Biology of erythtropoiesis, erythroid differentiation and maturation," in Hematology, R. Hoffman, E. J. Benz, S. J. Shattil et al., Eds., pp. 276-294, Elsevier, Philadelphia, Pa, USA, 5th edition, 2009.

[6] I. L. Weissman and J. A. Shizuru, "The origins of the identification and isolation of hematopoietic stem cells, and their capability to induce donor-specific transplantation tolerance and treat autoimmune diseases," Blood, vol. 112, no. 9, pp. 3543-3553, 2008.

[7] P. M. Lansdorp, H. J. Sutherland, and C. J. Eaves, "Selective expression of CD45 isoforms on functional subpopulations of CD34+ hemopoietic cells from human bone marrow," Journal of Experimental Medicine, vol. 172, no. 1, pp. 363-366, 1990.

[8] T. Papayannopoulou, M. Brice, D. Farrer, and K. Kaushansky, "Insights into the cellular mechanisms of erythropoietinthrombopoietin synergy," Experimental Hematology, vol. 24, no. 5, pp. 660-669, 1996.

[9] L. Chen, Z. Gao, J. Zhu, and G. P. Rodgers, "Identification of CD13+CD36+ cells as a common progenitor for erythroid and myeloid lineages in human bone marrow," Experimental Hematology, vol. 35, no. 7, pp. 1047-1055, 2007.

[10] T. Papayannopoulou and D. T. Scadden, "Stem-cell ecology and stem cells in motion," Blood, vol. 111, no. 8, pp. 39233930, 2008.

[11] C. J. Eaves and A. C. Eaves, "Erythropoietin (Ep) dose-response curves for three classes of erythroid progenitors in 
normal human marrow and in patients with polycythemia vera," Blood, vol. 52, no. 6, pp. 1196-1210, 1978.

[12] L. Douay, H. Lapillonne, and A. G. Turhan, "Stem cellsA source of adult red blood cells for transfusion purposes: present and future," Critical Care Clinics, vol. 25, no. 2, pp. 383-398, 2009.

[13] A. R. Migliaccio, C. Whitsett, and G. Migliaccio, "Erythroid cells in vitro: from developmental biology to blood transfusion products," Current Opinion in Hematology, vol. 16, no. 4, pp. 259-268, 2009.

[14] G. Migliaccio, R. Di Pietro, V. Di Giacomo et al., "In Vitro mass production of human erythroid cells from the blood of normal donors and of thalassemic patients," Blood Cells, Molecules, and Diseases, vol. 28, no. 2, pp. 169-180, 2002.

[15] G. Migliaccio, M. Sanchez, F. Masiello et al., "Humanized culture medium for clinical expansion of human erythroblasts," Cell Transplantation, vol. 19, no. 4, pp. 453-469, 2010.

[16] E. van den Akker, T. J. Satchwell, S. Pellegrin, G. Daniels, and A. M. Toye, "The majority of the in vitro erythroid expansion potential resides in CD34- cells, outweighing the contribution of CD34+ cells and significantly increasing the erythroblast yield from peripheral blood samples," Haematologica, vol. 95, no. 9, pp. 1594-1598, 2010.

[17] S. L. Erlandsen, A. G. Bittermann, J. White, A. Leith, and M. Marko, "High-resolution CryoFESEM of individual cell adhesion molecules (CAMs) in the glycocalyx of human platelets: detection of P-selectin (CD62P), GPI-IX complex (CD42a/CD42b $\alpha, \mathrm{b} \beta)$, and integrin GPIIbIIIa (CD41/CD61) by immunogold labeling and stereo imaging," Journal of Histochemistry and Cytochemistry, vol. 49, no. 7, pp. 809-819, 2001.

[18] G. Migliaccio, A. R. Migliaccio, M. L. Druzin, P. J. V. Giardina, K. M. Zsebo, and J. W. Adamson, "Long-term generation of colony-forming cells in liquid culture of CD34+ cord blood cells in the presence of recombinant human stem cell factor," Blood, vol. 79, no. 10, pp. 2620-2627, 1992.

[19] G. Migliaccio, A. R. Migliaccio, and J. W. Adamson, "The biology of hematopoietic growth factors: studies in vitro under serum-deprived conditions," Experimental Hematology, vol. 18, no. 9, pp. 1049-1055, 1990.

[20] K. E. McGrath, P. D. Kingsley, A. D. Koniski, R. L. Porter, T. P. Bushnell, and J. Palis, "Enucleation of primitive erythroid cells generates a transient population of "pyrenocytes" in the mammalian fetus," Blood, vol. 111, no. 4, pp. 2409-2417, 2008.

[21] T. Tallone, C. Realini, A. Böhmler et al., "Adult human adipose tissue contains several types of multipotent cells," Journal of Cardiovascular Translational Research, vol. 4, no. 2, pp. 200210, 2011.

[22] A.R. Migliaccio, V. Tirelli, F. Masiello et al., "High levels of CD44 expression identify hematopoietic cells capable of generating great numbers of erythroid cells under HEMA conditions," Blood, vol. 116, no. 21, 2010.

[23] K. Chen, J. Liu, S. Heck, J. A. Chasis, X. An, and N. Mohandas, "Resolving the distinct stages in erythroid differentiation based on dynamic changes in membrane protein expression during erythropoiesis," Proceedings of the National Academy of Sciences of the United States of America, vol. 106, no. 41, pp. 17413-17418, 2009.

[24] A. Fujimi, T. Matsunaga, M. Kobune et al., "Ex vivo large-scale generation of human red blood cells from cord blood CD34+ cells by co-culturing with macrophages," International Journal of Hematology, vol. 87, no. 4, pp. 339-350, 2008.
[25] T. M. A. Neildez-Nguyen, H. Wajcman, M. C. Marden et al., "Human erythroid cells produced ex vivo at large scale differentiate into red blood cells in vivo," Nature Biotechnology, vol. 20, no. 5, pp. 467-472, 2002.

[26] J. A. Chasis and N. Mohandas, "Erythroblastic islands: niches for erythropoiesis," Blood, vol. 112, no. 3, pp. 470-478, 2008. 

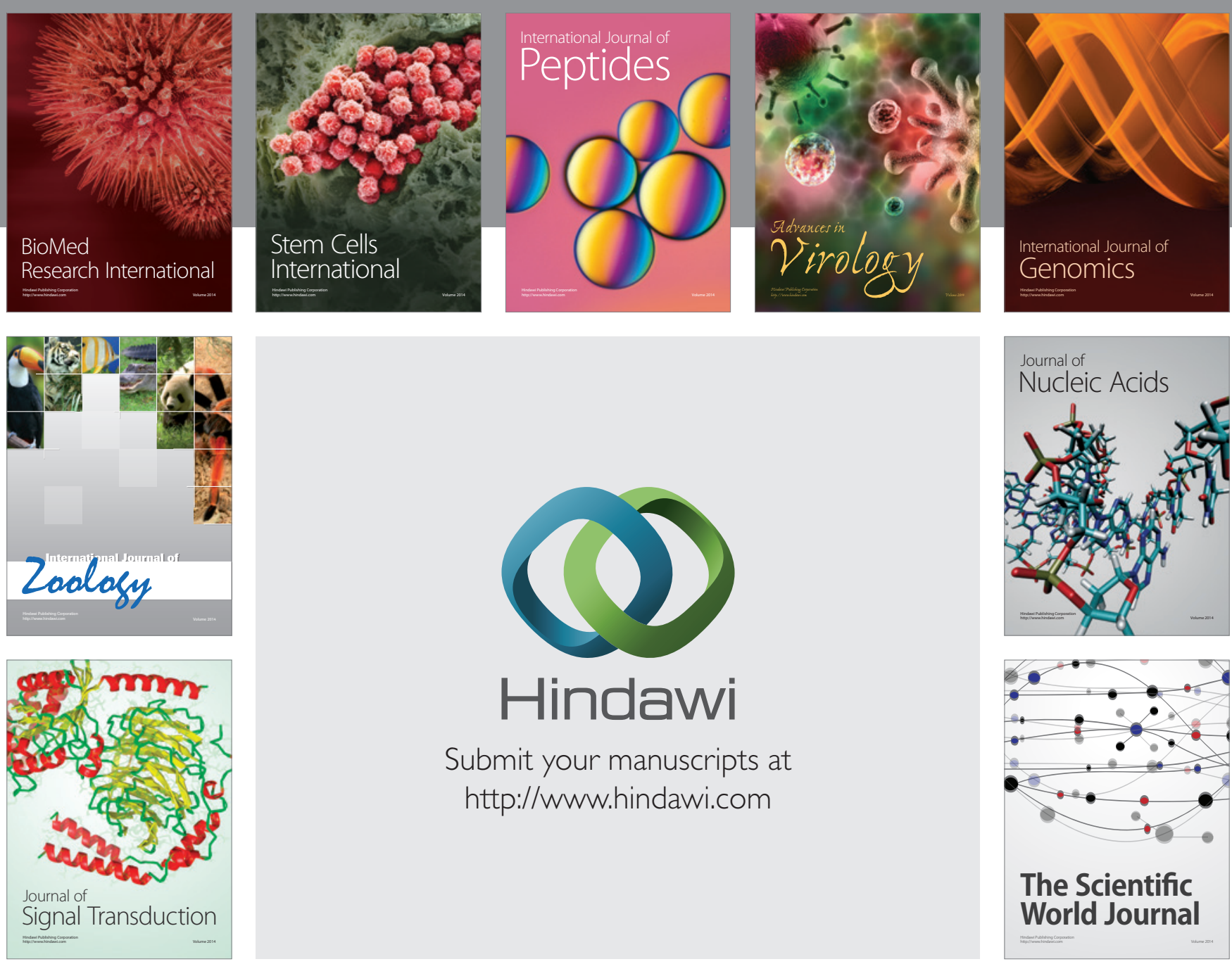

Submit your manuscripts at

http://www.hindawi.com
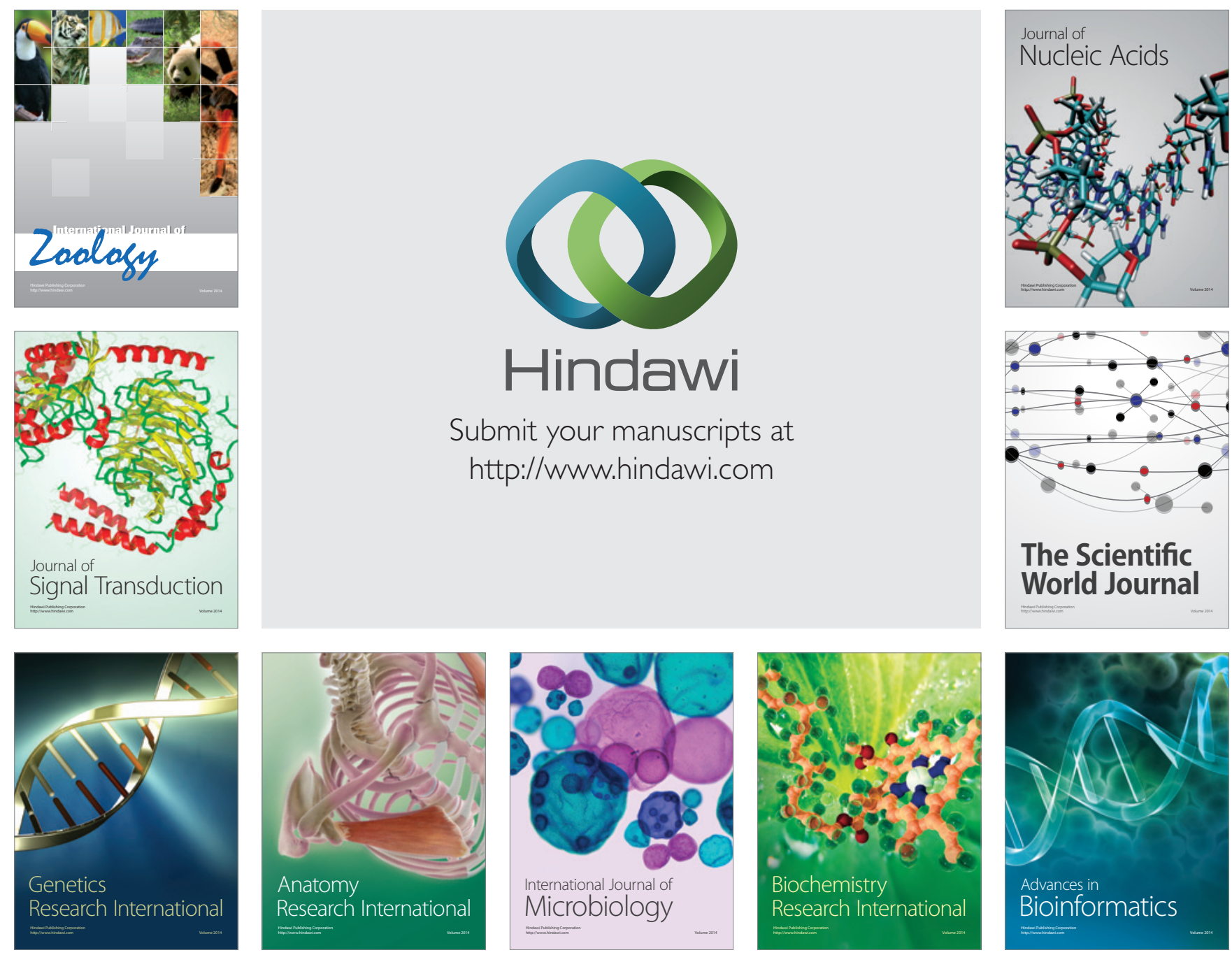

The Scientific World Journal
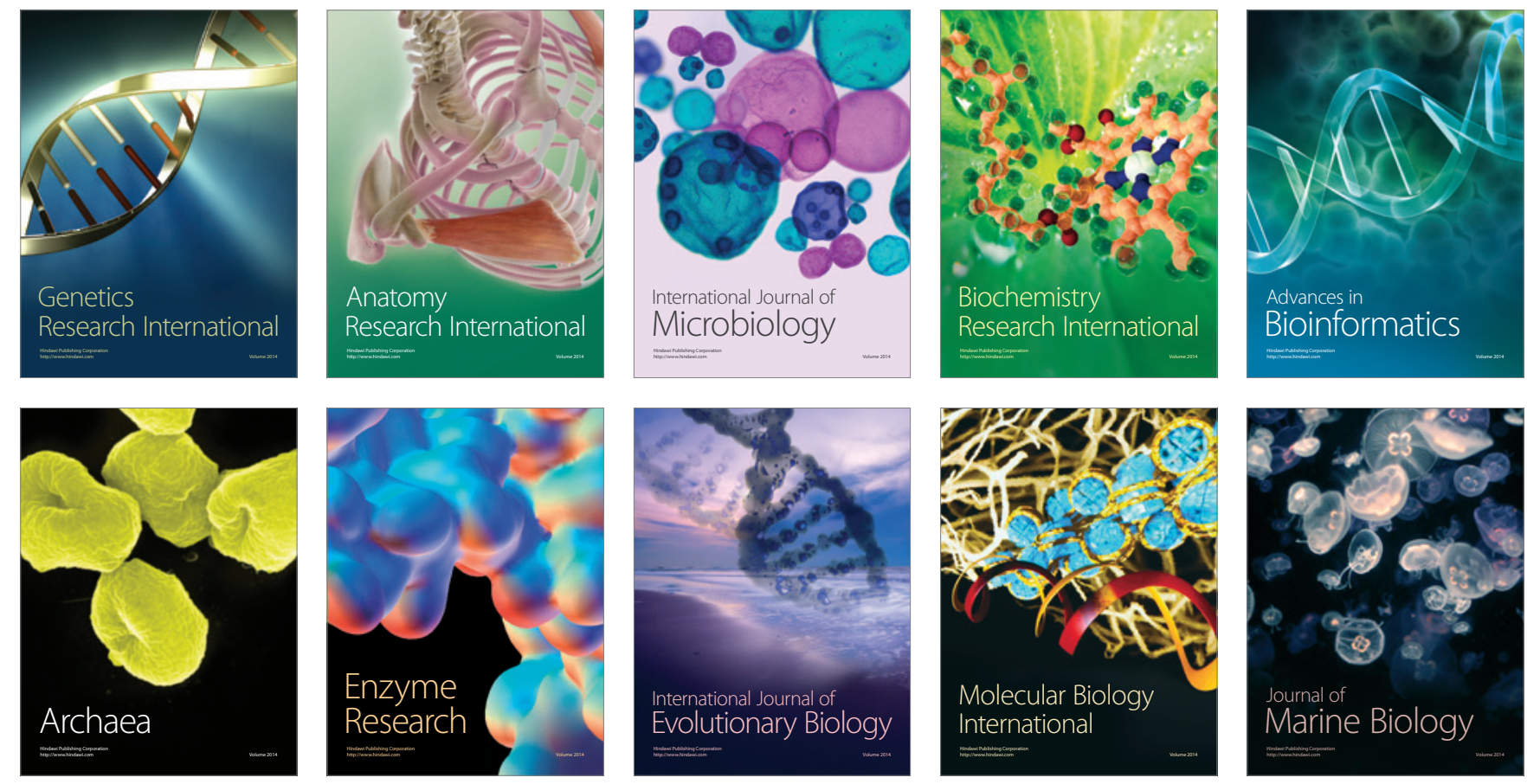